\title{
Hâsya: Towards a Poetics of the Comic
}

\author{
Jagannath Basu \\ Assistant Professor of English, Sitalkuchi College, India. Orcid: 0000-0003-0306-7238. \\ Email:dyukrish@gmail.com
}

\begin{abstract}
:
Amidst a whole range of criticism and derision that laughter has received down the ages, the question still lingers: why "One daren't even laugh any more"? The comic, according to Aristotle, is associated with the ridiculous or the ugly. It constitutes a deformity or an error and leans towards something which is mean. The comedy, on the other hand, is a form of low art consisting of what is base or inferior. This view of the comic and comedy has largely been accepted and forwarded by the West. They have looked down upon the comic with a one-dimensional view of derision and condemnation. However, "to comprehend the comic is to risk overlooking the structure of incomprehensibility that is crucial to its operation" (Trahair, 2007, p.15). Often considered as a synonym for humour or laughter, hâsya, on the other hand, within the sphere of Indian Aesthetics, always enabled us to understand comic's implications in the object world and vice versa. Hâsya is not only enigmatic but also esoteric in nature. Through a select study of VidûSaka (the deformed clown in Sanskrit theatre) and two poems- one a Sanskrit Muktaka and the other a Nindā-stuti, this paper intends to read the potentialities of hâsya as an-other laughter, not just as a mode of gay affirmation or subversion but as a mode of "free play" $(j u)$, within the space that exists between the self and the other(s). This, however, by no means is an attempt to conceive hâsya only as a disruptive event with the intentions of the "Empire writing back', rather a wish to hermeneutically comprehend the harmony of the comic within the dimensions of Indian aesthetics, so that the poetics of laughter can be retrieved and reclaimed.
\end{abstract}

Keywords: Hâsya, laughter, being, other, comic, poetics, $j u$

\begin{abstract}
We need to address more attention to the way cultures outside the European-American context both laugh and conceptualize laughter for themselves. It is not enough, in fact it is surely detrimental, to merely place our preconceptions about what laughter is and must do onto other cultures, not only because it is culturally insensitive but because we surely have much to learn, even about ourselves, by broadening our gaze and listening to other voices on the subject.
\end{abstract}

-Mark Weeks, “Abandoning Our Selves to Laughter: Time and the Question of Self-Loss in Laughter"

In 1530, Erasmus in his book De Civilitate lays down the concept of laughter and its relation to "good breeding":

To laugh at every word or deed is the sign of a fool; to laugh at none the sign of a blockhead. It is quite wrong to laugh at improper words or actions. Loud laughter and the immoderate mirth that shakes the whole body and is for that reason called "discord" by the Greeks, are unbecoming to any age but much more so to youth. The neighing sound that some people make when they laugh is also unseemly. And the person who opens his mouth wide in a rictus, with wrinkled cheeks and exposed teeth, is also impolite. This is a canine habit and

(C) AesthetixMS 2021. This Open Access article is published under a Creative Commons Attribution Non-Commercial 4.0 International License (http://creativecommons.org/licenses/by-nc/4.0/), which permits non-commercial re-use, distribution, and reproduction in any medium, provided the original work is properly cited. For citation use the DOI. For commercial re-use, please contact editor@rupkatha.com. 
is called a sardonic smile. The face should express mirth in such a way that it neither distorts the appearance of the mouth nor evinces a dissolute mind. Only fools use expressions like: "I am dissolving with laughter," "I am bursting with laughter," "I am dying with laughter." If something so funny should occur that it produces uncontrolled laughter of this sort, the face should be covered with a napkin or the hand. To laugh when alone or for no obvious reason is put down to either stupidity or insanity. (Erasmus, 1985, pp. 275-276)

It must be noted that in the sixteenth century western Europe, this book was widely followed as a standard textbook dealing with manners, customs, appropriate behaviour, politeness and all the necessary parameters pertaining to school education. This is a clear case where Erasmus is acting on behalf of the West's strenuous attempts to construct a binary between the civilized and cultured aspects of the smile as opposed to the savage and primitive aspects of laughter (also noted by Anca Parvulescu in her book Laughter). But as Beckett says, "it's not the same thing":

Vladimir breaks into a hearty laugh [bon rire] which he immediately stifles [réprime], his hand pressed to his pubis, his face contorted.

Vladimir: One daren't even laugh any more [On n'ose même plus rire].

Estragon: Dreadful privation.

Vladimir: Merely smile. (He smiles suddenly from ear to ear, keeps smiling, ceases as suddenly.) It's not the same thing. Nothing to be done. (Pause.) Gogo. (Beckett, 2006, 13)

The overpowering and all-encompassing "smile" in the western epistemology has time and again limited laughter by construing a metanarrative of exclusion, thereby bypassing the authenticity of what laughter is. It has never tried to listen to its resounding voice(s), thereby missing the tales that laughter had to tell.

Whether in Hindi, Sanskrit, Prakrit or Marathi, hâsya can loosely be translated as humour or laughter. It is one of the eight rasas (flavour or sentiment) or bhâva (mood) and has a unique place in the history of the poetics of the comic. Hâsya is one of the significant tropes in understanding the subject's implications in the material world and vice versa. Within the sphere of Indian Aesthetics, hâsya is not only enigmatic but also esoteric. There has been considerable debate on the distinction between hâsya and hāsa and their correlation to humour and laughter. Bharata Muni, and later on Abhinavagupta were divided as to their (hâsya/hāsa) nature and correspondence as well as their perception. Nāṭyaśāstra prescribes that "the comic has as its basis the durable psychological state of laughter." Sunthar Visuvalingam, one of the leading scholars on this topic states,

Hâsa/hâsya is the most problematic among the bhâva/rasa distinctions but is nevertheless valid. Hâsa is a personally involved worldly reaction that is pleasurable only due to the discharge of tension, whereas hâsya is the active skill of relishing the emotional bisociation itself that can dispense with laughter. (Visuvalingam, 1983, p. 91)

Without concentrating too much on this divide between hâsya/hāsa, this paper tries to comprehend hâsya as an onto-epistemological category not merely as an unruly event with the aims of the 'Empire writing back', but to comprehend the poetics of the comic in the manner of a harmony so that the aesthetics of laughter could be salvaged and asserted. Osho, in his book The Dhammapada: The Way of the Buddha says, "When you laugh, suddenly laughter is there, you are not. You come back when the laughter is gone" (quoted in Weeks, 2013, 64). This ego(less)ness is fundamental to comprehend hâsya. Hâsya is a resonance, a vibration, it is the way of moving and being moved - 
to be on edge of meaning, or in an edgy meaning of extremity, and as if the sound were precisely nothing else than this edge, this fringe, this margin, - at least the sound that is musically listened to, that is gathered and scrutinized for itself, not, however, as an acoustic phenomenon (or not merely as one) but as a resonant meaning, a meaning whose sense is supposed to be found in resonance, and only in resonance. (Nancy, 2007, p. 7, italics in original)

Hâsya is about making sense of the absurd, it is an event where consciousness operates within a sub-liminal space between attachment (parigraha) and non-attachment (aparigraha). Hâsya helps one to comprehend the poetics of the comic, not just as a mode of gay affirmation or subversion but as a mode of "free play" $(j u)$.

Hâsya is magico-realistic, Brockett mentions, and in the South Asian context, recreation and magic were always intermixed with hâsya and formed an integral part of the theatre from its very inception. Such a tradition has similarities with what is known as "Pleasure plays" performed by the primitive tribes of Australia, Philippines and Africa where it was primarily used for "warding off evil" by ridiculing unfriendly spirits, unsuccessful spirits, or for hunting tactics or socially unacceptable behaviour (Varadpande, 1987, p. 8). Mark Weeks in his article "Abandoning Our Selves..." mentions about a Bhutanese scholar, Karma Ura, who in turn directed him to an article by a Thai scholar Soraj Hongladarom entitled "Language, Reality, Emptiness and Laughs" which says: "One laughs... as an integral part of, an expression of, Emptiness itself" (quoted in Weeks, 2013, p. 19). For Hongladarom, this kind of an experience, as Weeks points out, belongs to a particular Buddhist tradition, and the fact that it is based on the notions of nothingness, absence and evacuation tends to justify it. In hâsya, consciousness is ruptured with the prospects of (re)configuration, a transition from "being-in-order" to "being-out-of-order", finally towards the eventual "being-(in)order" - a form of "constant-consciousness" (a creative-destructive-recreativeprocess).

Hâsya triggers an "overturning, for an instant, of a certain mind-body hierarchy" (Weeks, 2013, 61). In hâsya, being does not exist in time, but is time (Loy, 1986, p. 19). Time, in hâsya, ceases to remain Time per se, but as Maurice Merleau-Ponty says, "we are not saying that time is for someone...we must understand time as the subject and the subject as time" (Ponty, 1962, p. 490, italics in original). Rather than producing an Enlightenment idiom, hâsya accentuates comic's potentialities and possibilities. It evokes both the "laughter with(in)" and the "laughter with(out)", an occurrence that protects by destroying itself.

VidûSaka (the deformed clown of the Classical Sanskrit theatre), for example, often used to evoke the "hâsya rasa" (one of the eight rasas mentioned in the Nāṭaśāstra) and therefore, in return, could listen to the voice(s) of the comic. His actions are often reflections of what is at stake within the comic processes and functions. Unlike the western Fool, VidûSaka not only seeks to problematise and subvert the Brahminical conventions and the casteist forms of life they seek to sustain, it also blasts open the top-bottom concept inherent within the Brahmanical system. He moves deeper into the system's reality, thereby unearthing the grim truth beneath the covered intentionality. The "material principle" that defines VidûSaka to a large extent implies to that which is void of any strict authoritative principle. He is a perfect example of what Mikhail Bakhtin would term as "the dual bodied world of becoming". VidûSaka has never been subjected to the dreadful privation that the West had always thrusted upon to fulfill the task of "good breeding". That is perhaps the reason why the Fool in the western literary history has never been able to provide something significant other than mere comic relief. The "comic relief" within the western epistemology, however, was a meager show, a mere relief, so that by projecting a contrary (albeit a weak contrary), sometimes the binary could more genuinely and strongly be established. The Fool 
therefore, had neither been instrumental in his battle against the officialdom, nor in his efforts to disrupt its inherent hierarchical structures. VidûSaka, on the other hand, interrogates the "interpellative process" that intended to suppress the overflow of energy, of erotico-comic potentialities. VidûSaka's essential comicality, his erotic, disruptive and distorting fits of laughter, are means through which the poetics of the comic upsets the tenets of formal artistry often obliged through discursive proficiency. The variety of satiric and mimicry strategies that VidûSaka imbibes in the Sanskrit Theatre serve to deflate the conventional symbolic contours, reducing literary and social customs at odds with bald literalness, thereby proposing a deranged commentary on the snooty pretentions of grace and sophistication. He has ordinary and common ambitions which stand in direct opposition to the cultured sophistication of the Fool. It seems that VidûSaka had always been on a secret journey, a journey whose secret lies with everyone but very few are able to unravel. He evokes utmost serious thought in the most nonserious manner.

VidûSaka is past as well as contemporary; he is "anachronic". He is the sutradhara- the "holder of strings". He is thus, well equipped with the Rasabhasa - the language of the Rasa - that is essential for building a connection (the conjunction — "and") which is critical for hâsya's operation. There is a certain joy that exists in this connection, a joy that cannot be attained by the contours of epistemology, a joy that can only be felt in the shared laughter of primitivity. VidûSaka's atihâsya (explosive or excessive fits of laughter) from time to time in the midst of his antics ensures that the contagious nature of his hâsya is spread among the audience who joins the chorus. He renegotiates hâsya's capacities to capture contingency and violence aesthetically, especially through literary form, and evokes a sense of liberation which is very playful in nature. VidûSaka thus, thwarts the transformation of the distorted, anarchic individuals into cultured, well-refined rational citizens (what Erasmus or the West in general had hoped for).

Vladimir's sudden eruption into laughter and his subsequent self-prohibition not to "laugh any more" in Beckett's Waiting for Godot is a grim reminder of how the West always tried to control and limit the body-in- laughter. As observed by Anca Parvulescu in her book, Laughter: Notes on a Passion, Physiognomical or Gelatoscopical readings have always suggested the "laughing face" as an enigmatic site of contestation. The image of the laughing face was seen as an anarchic and primitive space, an act of disbursement or dissolving, or at best a loss of control. It was always suggestive of unbridled excess of profane and turbulent emotions that threatened to destabilize the Renaissance control of the mind over the body. Through its multiple openings, the "laughing face" of VidûSaka disturbs the very structure of the bios that the Renaissance Humanists were very keen on maintaining. It seems to be too copious and too fractious that wouldhinder the process of "good breeding". Such an event may well be seen in the light of the Zen Buddhist concept of apahasita (an important concept in Zen Buddhism which refers to loud fits of laughter that brings tears to the eyes, usually associated with the lower caste). VidûSaka's apahasita or what many would call savage or primitive, is a stipulation of the Zen Kōan where one laughs amidst crying and cries amidst laughing (Carter, 2010, p. 89).

There is a deconstructive approach towards this idea of hâsya and the aesthetics of presence, "deterritorialising" the swerving and unswerving forms of union between the logos of the subject and the telos in the object. Being outside the "core" or "mainstream" enables VidûSaka to coordinate measurable existential domains, it gives him a certain kind of agency on multiple sides of the same narrative and consequently acknowledges the truth of each side. The agency of VidûSaka, therefore, is one of its own kind: it is different and autonomous - a typical postmodern symptom of "petit clown" noticeable only in the comprehension and encounter of his self with innumerableirreducible-other(s). 
5 | Hâsya: Towards a Poetics of the Comic

Another aspect of hâsya can be observed in the Sanskrit Muktakas where the omnipotent, omniscient God is often humanized to the extent that he tends to lose his divinity. One such Muktaka is from the Subhāșitaratnakoșa involving the characters of Śiva and Pārvati and their younger son Guha (sometimes referred to as Murugan or Kārttikēya):

mātar jīva kim etad añjalipuțe tātena gopāyitam

vatsa svādu phalam prayacchati na me gatvā grhāna svayam

mātraivaṃ prahite guhe vighațayatyākrșya saṃdhyā̃̃jalim

śambho bhagnasamādhiruddharabhaso hāsodgamaḥ pātu vaḥ

"Mommy, tell me, what is that

in the palm of Daddy's hand?"

"That's jujube fruit, my little darling."

"He won't give it to me!"

When his mother said, "Go and get it,"

Little Guha forced open the hands clasped in twilight meditation;

Siva's trance was broken,

thoughts were interrupted,

and he laughed.

May the burst of his laughter protect you"!

— "Saduktikarṇāmṛta." 1.8.3. Subhāșitaratnakoșa. 4. 30. Lee Siegel, (Trans.)

Pramatha is one of the many names of addressing the Siva. Pramatha is also regarded by Bharata Muni as the deity of "Hâsya Rasa". Manohar Laxman Varadpande mentions that in many Himalayan tribal festivals Śiva

is regarded as a presiding deity of theatre and his connection with humour is acknowledged by the great sage Bharata himself. He has mentioned Pramatha as a deity of Hasya Rasa. Pramatha is one of the numerous names of Shiva and also denotes a certain class of his Ganas, associates [...] Bharata has also established relationship between the erotic and the comic. "A mimicry of erotic", he says, "is called comic". According to him, Hasya originated in Sringara. However, he forbade obscenity on the stage. Taking into consideration the interest of the people in comic-erotic situations in drama, Bharata remarks that "common women and uncultured men are delighted by them." He also says, "this sentiment is mostly seen in women and men of inferior type". Obviously, here Bharata, the creator of sophisticated classical drama, is referring to the fun loving folk audience and their crude humour. (Varadpande, 1987, p. 8)

The laughter of Śiva here, is an erotico-comic occurrence (hâsya) which derives its autonomy from this continuous and uninhibited $j u$ (free play). Unlike what we typically associate Siva with (the raging, destructive Śiva especially when interrupted during his meditation), the "burst of laughter" is a moment of rupture where our very consciousness of the Supreme Other (Śiva) is met with a Destrucktion, dissolving the binaries between the "sacred" and the "sacrilegious" and presenting the burst in the form of the World itself. Hâsya here acts as an awareness of the Other, where the bridge between the being-of-the-subject and the being-of-other(s) is formed.

France Bhattacharya observes that satire here "can be understood as a way to present Siva's divine nature that is beyond human understanding... It emphasizes the unresolved contradiction between the opposites present in his nature" (Bhattacharya, 2012, p. 66). For Hindus, these absurdities are "like bifocal glasses, we hold multiple visions simultaneously, moving from one to another seamlessly" (Rao, 2016). "When it comes to conjunctions, we Hindus have, in general, 
preferred 'and' to 'or'”, says Rao (Rao, 2002). Nikhil Mandalaparthy is therefore correct when he says:

the audience aren't the only ones laughing; the gods themselves laugh at the humor of their situations [...] it is the gods' own experience of hāsya [...] Śiva's amusement at his son's curiosity - that the poet prays to for protection. This focus on the laughter of the gods as a positive, benign force is quite interesting. The ability to laugh at oneself is a very human trait, and when applied to the Hindu gods and goddesses, it humanizes them in the eyes of a devotee. (Mandalaparthy, 2017)

Unlike in the western religion, approaching the Hindu gods through hâsya was never perceived as sacrilegious or invasive. In this instance, with its $j u$ (free play), it relies on the underlying concept of bhakti (devotion) through conjunction - the "and", not "or". Unlike the western concept of devotion, it lets the devotee to connect more spontaneously with the Param Brahma or the Supreme Other. Wendy Doniger argues that "the humor and disrespect with which the deities are treated served to relieve various tensions... . On a cosmic level, too, humor in myth serves to highlight some rather serious theological components: dimming the opposites, the inverse effect, subjective reserve, the grotesque..." (Wendy, 1982, p. 74). France Bhattacharya affirms that the "revilement" of Śiva was prevalent even in precolonial Bengali literature which often humanized "Śiva by underlining his weakness and failures" (Bhattacharya, 2012, p. 67). It acted as "a relief for simple, ordinary men to see the great god as one of them" (p. 67).

Hâsya therefore, makes the "gods more accessible to the human devotee ... [who in turn] are enmeshed in the paradox of viewing divinity both as mundane and supernatural. This paradox is at the heart of bhakti, and it is made manifest by" hâsya (Mandalaparthy, 2017). In Hinduism, there is always a curious interplay between the lìla (casually interpreted as play) of the gods and the māya (illusion) created by them. The poem, by humanizing Siva with all human emotions, involves him in all the ups and downs that human beings face in their married life and in their pleasures of parenting. The poem thus, transports the divine Siva into the mundane world of human relationships. It invokes "the grace and protection that is latent in the laughter of these almosthuman gods" (Mandalaparthy, 2017). The whole of the universe that "listens" and responds to Śiva's laughter emerge with their own laughing voice(s) - making it almost like a performance or a religious ceremony - a yajna. It is not really moral or ethical, rather it has an ulterior comic dimension that problematizes the rubric of meaning-generation-machine that the western Enlightenment was so obsessed with.

Unlike the Muktaka, in Nindā-stuti hâsya is used for the same purpose but with a difference in tone. Here, there is no vertical downward movement of the divine, rather the devotee moves upwards towards the God. There is an intrinsic "surprise" value beneath the tone of these poems primarily, as Mandalaparthy says, born out of the devotee's irreverent tone. The end result however, is always the same as in every case the inherent essence is about a transformation from a vertical descendance/ascendance towards a horizontal/equal sphere of attachment.

The following poem by Kāsula Purușottama Kavi, dedicated to the form of Vishnu, is a stanza from the Āndhra-nāyaka-śatakamu:

“ālu nirvāhakurālu bhūdēvi yai yakhilabhārakun̆ ḍanunākhan̆ decce nișțasamipannurā limidira bhāryayai kāmitārthadun̆ ḍannaghanată̆ deccĕ gamalagarbuñḍ srșțikarta tanūjun̆ḍi bahukuțumbakun̆ danna balimin̆deccen̆ galușa vidhvamisini gañga kumāri yai batita pāvanun̆ danna pratibhan̆ decce ānḍrubiḍdalu deccu prakhyātilēvi 
modaținuñdìu nīvu

dāmōdarun̆ḍave citra citra

prabhāva, dākșinyabhāva, hata

vimatajīva, śrīkāku!̣andhradēva"!

"Your wife, the Earth, is the stable one.

Because of her, they say you can bear anything.

Your other wife, Goddess of Wealth, gives what people want.

Because of her, people say you are generous.

Brahma, who creates the world, is born out of you.

That's why people think you're a big family man.

The Ganges, who washes away evil, is your daughter.

She's made you into someone who redeems the fallen.

It's your wives and children who bring you fame.

In yourself, god of many miracles, from the beginning

you're a good-for-nothing".

- (Āndhra-nāyaka-śatakamu stanza 26. Rao and Shulman, (Trans.)

Narayana Rao and Shulman note that the "punch-line" of this poem lies in the phrase "In yourself [...] from the beginning you're a good-for-nothing" (Rao and Shulman, 2002, p. 248). They remind us that in colloquial Telugu, dāmōdara is not only the name of lord Vishnu, but it actually means "good-for-nothing". By creating this "tone of taunting and [by] upbraiding the deity" the bhakt (devotee) here not only shocks the divine nature of lord Vishnu but also rises vertically towards the divine (p. 248).

As Nikhil Mandalaparthy says,

For all its humor and sarcasm, this poem does not necessarily humanize Vișnu or indeed any of the other deities mentioned. Here, they are not portrayed with human emotions in the same way one would see in a Sanskrit muktaka. Purușottamakavi uses fairly typical epithets to describe the gods and goddesses - "one who redeems the fallen" (batita pāvanun̆) and "one who fulfills desires" (kāmitārtha) — as he deconstructs Vișnu's glory while simultaneously maintaining his status as a deity. By the end of the poem, Vișnu's status as a god hasn't changed, and the refrain reminds the reader that he is ändhradēva, "God of Andhra." The humor of the nindā-stuti comes from the way the poet deconstructs the god from behind-the-scenes, all while leaving the "façade" of the god intact. The audience is left to ponder this paradox, which usually ends in laughter. (Mandalaparthy, 2017)

The poem is an instance where the worshipper attains the stature of the jnaani (one who realizes his oneness with God). As a spatio-temporal vertical movement, the devotee transgresses the limits of the telos, as it is in this movement that the self transcends itself and takes a flight towards the Supreme Other (Vishnu). Hâsya here lies not only in sublimation of the self but also in sublation (transcendence). And this vertical movement towards the divine Vishnu is not a mere abnegation of the devotee, rather a transcendence. In capturing the essence of this transcendence, the agency serves as an ontological counter-point in the faith of the worshipper, thus the agency never totally dissolves and discloses itself. It rather acts like a catalyst and as a product itself in this divine operation.

This provides a certain autonomy to the devotee which in turn posits its presence by being in a state of quantum-absence, not by its negation but by its pervading assertion in seeking the "truth" and its existence residing in its faith, keeping the individual narrative and rendition open to 
a state of free play $(j u)$. The devotee is thus a being eternal in its performance and serving "as" and "for" the Supreme Other (Vishnu). The devotee attains a consciousness, a "pure consciousness" - free from any limitations, serving as the reference in itself (not in the form of the transcendental signifier, but in a more open ended and self-reflexive manner) which in the facade of hâsya operates between the devotee and the devotion towards lord Vishnu. This presents itself as a counter-discourse to the hegemonic concept of the Divine as we find in western religion. And it is in this (en)counter, that one not only embodies the essence of the purely divine but also finds a space for generating different narratives within the same discourse; and in its scheme of challenging and disrupting, evokes its carnivalesque nature. This paves the way for a potential existence of a state of equilibrium between the devotee or the bhakt and lord Vishnu not in the binaries of the either-or, rather in a condition of its "quantum-jump", 2 in a kind of persistent shifting between the states of the (un)apprehended static becoming(s) and its very micro-becoming(s).

\section{Notes}

${ }^{1}$ This term was originally used by Martin Heidegger, the German philosopher, indicating an "original selfforming of an essential unity of ontological knowledge" (quoted in Luchte, 2008).

${ }^{2}$ A concept introduced by Niels Bohr, "quantum jump" is the unexpected and sudden shift of a quantum system from one energy level to another or from one quantum state of existence to another. Here, the devotee and the god, both acting as atoms and molecules within a (quantum) system are also in a constant transition from one unmeditated state of existence into another (excitation), often producing a new state of equilibrium which is both abrupt and unexpected.

\section{References}

Bakhtin, M. (1984). Rabelais and His World (H. Iswolsky, Trans.). Bloomington \& Indianapolis, Indiana University Press.

Beckett, S. (2006). En attendant Godot/ Waiting for Godot. New York, Grove Press.

Bharata, M., \& G. R. S. Iyengar. (1977). Natyasastra: Translation of Bharatha Natyasastra. Bangalore, Suvani Prakasana.

Bhattacharya, F. (2012). Satire in Pre-Colonial Bengali Literature: Siva, an Object of Revilement and Praise. In M. Horstmann and H. R. M. Pauwels (Eds.), Indian Satire in the Period of First Modernity. Wiesbaden, Harrassowitz Verlag.

Carter, R. E. (2010). Why do Birds Shit on Buddha's Head?: Zen and Laughter. In H. G. Moeller and G. Wohlfart (Eds.), Laughter in Eastern and Western Philosophies. München, Verlag Karl Alber Freiburg.

Erasmus, D. (1985). Collected Works of Erasmus, Vol. 25 (J.K. Sowards, Ed.). Toronto, University of Toronto Press. 275-276.

Hentschel K. (2009) Quantum Jumps. In D. Greenberger, K. Hentschel and F. Weinert (Eds.), Compendium of Quantum Physics. Berlin, Heidelberg, Springer. https://doi.org/10.1007/978-3-540-70626-7_170

Hongladarom, S. (2018, May 12-16). Language, Reality, Emptiness and Laughs. [Paper presentation]. 17 ${ }^{\text {th }}$ Symposium of the Academie du Midi. [Cited in Mark Weeks]

Inoue, H. (2003). Osaka no bunka to warai/Osaka's Culture and Laughter. Osaka, Kansai University Press.

Jayaram, V. Hindu God Lord Shiva (Siva) - the Destroyer. https://www.hinduwebsite.com/hinduism/siva.asp

Loy, D. (1986). The Mahayana Deconstruction of Time. Philosophy East and West, 36(1), 3-23. 
9 | Hâsya: Towards a Poetics of the Comic

Luchte, J. (2008). Heidegger's Early Philosophy: The Phenomenology of Ecstatic Temporality. New York, Continuum.

Mandalaparthy, N. (2017 December 18). Hasya and Hinduism: laughing at (and with) the gods. nikhiletc.wordpress.com. https://nikhiletc.wordpress.com/2017/12/18/hasya-and-hinduism/

Nancy, J. L. (2007). Listening (C. Mandell, Trans.). New York, Fordham University Press. (Original work published 2002).

Parvulescu, A. (2010). Laughter: Notes on a Passion. Massachusetts, The MIT Press.

Ponty, M. M. (1962). Phenomenology of Perception (C. Smith, Trans.). London, Routledge \& Kegan Paul.

Rao, V. N. (2016, April). Paradoxology: The Art of Praising the Deity. Harvard Divinity School. [Video]. https://www.youtube.com/watch?v=ocjKWs8GV9k

Rao, V. N. and Shulman, D. D (Trans. \& Eds.). (2002). Classical Telugu Poetry: An Anthology. Berkeley, University of California Press.

Siegel, L. (1987). Laughing Matters: Comic Tradition in India. Chicago, University of Chicago Press.

Trahair, L. (2007). The Comedy of Philosophy: Sense and Nonsense in Early Cinematic Slapstick. New York, SUNY.

Varadpande, M. L. (1987). History of Indian Theatre, Volume 2. Delhi, Abhinav Publications.

Visuvalingam, S. (1983). Abhinavagupta's Conception of Humour: Its Resonances in Sanskrit Drama, Poetry, Hindu mythology and spiritual practice. [Ph.D thesis, Banaras Hindu University].

Weeks, M. (2002). Laughter, Desire and Time. Humor: The International Journal of Humor Research, $15(4), 383-400$.

Weeks, M. (2013). Abandoning Our Selves to Laughter: Time and the Question of Self-Loss in Laughter. Israeli Journal of Humor Research, 3 (58-75).

Wendy, D. O. F. (2009). The Hindus: An Alternative History. New York, Penguin.

Wendy, D. O. F. (1982). The Shazam Syndrome: The Banalization of the Hindu Gods. In Women, Androgynes, and Other Mythical Beasts (pp. 65-76). Chicago, University of Chicago Press.

\section{Bionote}

Jagannath Basu is Assistant Professor of English at Sitalkuchi College, India. His publications include: The Portrait of an Artist as a Pathographer: On Writing Illnesses and Illnesses in Writing eds. (Wilmington, DE: Vernon Press, 2021); Geographia Literaria: Studies in Earth, Ethics and Literature eds. (Stuttgart: ibidem Press, forthcoming, 2021); "Derrida and the Art of Embalming: Thanatopraxie in 'Tithonus' and A Tale of a Tub." Journal of Foreign Languages and Cultures, Vol. 4 No. 2 Dec. 2020, 80-89, (Hunan Normal University) and "Moving back and forth of the I': Parasite and Para-site in Beckett's The Unnamable." Critical Survey, Vol. 34 No. 3 Summer, 2022, forthcoming, (Berghahn Journals). 